\title{
SŁAWOMIR PASIKOWSKI
}

\author{
UNIWERSYTET ŁÓDZKI
}

http://dx.doi.org/10.18778/8142-715-9.07

\section{Warunki krytyki metodologicznej prac badawczych}

\section{Wprowadzenie}

Krytyka uchodzi za podstawowy czynnik tworzenia wiedzy naukowej. Wystarczy wymienić zaledwie kilka powszechnie rozpoznawalnych stanowisk: Kartezjusza koncepcję wątpienia i ostrożnego uznawania sądów jako podstawy poznania pewnego i nowożytnej metody naukowej $(2002,2009)$, Karla Poppera ideę postawy krytycznej, która ma wyrażać się w wątpieniu i próbach obalania twierdzeń celem eliminacji błędów (1962), czy Kazimierza Ajdukiewicza postulat racjonalnej postawy, uznanej przez niego za warunek naukowej wypowiedzi $(1965,1983)$. Konstytutywną rolę krytyki daje się dostrzec także na społecznej płaszczyźnie aktywności naukowej. Ta bowiem tworzy się i rozwija w toku intersubiektywnej refleksji i oceny.

Krytyka zachodząca w nauce nieczęsto jednak staje się przedmiotem refleksji, mimo że uchodzi ona za konstytutywny czynnik aktywności naukowej na każdym z jej etapów - oceny efektów tej aktywności, komunikacji w społecznym środowisku nauki (por. Sławiński, 1998) - a także za probierz kondycji dyscypliny naukowej, w ramach której jest ona realizowana (por. Białynicki-Birula, 1998; Pelc, 1998). Stanowi ponadto podstawę kluczowych procesów konstytuujących naukę, tzn. awansów naukowych, autorytatywnego upowszechniania rezultatów badawczych oraz przyznawania funduszy na działalność naukową. 
Słownikowe wykładnie wiążą pojęcie krytyki z greckim wyrazem kritike oznaczającym sztukę osądzania i rozstrzygania. Współcześnie pojęciu temu przypisywane są różnorodne i częstokroć niewykluczające się znaczenia. Jest ona bowiem definiowana jako wytwór i czynność (Pelc, 1998) ocena (Białynicki-Birula, 1998; Pelc, 1998), jak też działanie językowe lub działanie komunikacyjne (Hanus, 2018). W każdym z tych znaczeń nieodłącznie wiąże się z zagadnieniem przyjmowanych kryteriów. Z tego zapewne powodu zwykle identyfikowana bywa z wartościowaniem, w tym z jego formą szczególnie bliską nauce, czyli z recenzowaniem (por. Pieter, 1967; Sternberg, 2011). Rzadziej natomiast - wprost z dążeniem do porozumienia, doskonalenia tego, co podlega krytyce (Koj, Mordyka, 1993), dyskusją, perswazją, porównywaniem (por. Białynicki-Birula, 1998; Goćkowski, 1998; Jackowski, 1998; Koj, Mordyka, 1993; Pelc, 1998; Szacki, 1998), pomiarem (por. Białynicki-Birula, 1998; Świderski, 1998), jak też osobnym rodzajem działalności twórczej (Pieter, 1967, s. 24), które zasadnie pojęcie krytyki dookreślają. Wskazują one przy tym nie tylko na jej funkcję selekcyjną czy nawet eliminacyjną, jeśli weźmie się pod uwagę pojmowanie krytyki jako zwalczanie konkurencyjnych stanowisk (Goćkowski, 2001; Koj, Mordyka, 1993), lecz także analityczną, informacyjną, pedagogiczną, doradczą i heurystyczną. Idąc tym tropem, należałoby również wspomnieć o wskazywaniu roli krytyki stymulującej postęp w nauce. Miałaby ona polegać na korygowaniu wad, odkrywaniu i pokazywaniu alternatywnych kierunków myślenia i działania naukowego, w tym precyzowania idei, stanowisk czy też samego języka, w którym są one wyrażane (Koj, Mordyka, 1993; Pieter, 1967, s. 276). Jak zatem widać, zakres własności i zadań, zapewne słusznie wiązanych z krytyką naukową, przedstawia się szeroko. Nie ułatwia to określenia jej sensu. Znaleźć można jednak trop wskazujący, że wyraża się on w zabieganiu o „prawdę naukową” (Goćkowski, 2001) albo, ogólniej, w kontrolowaniu i redukowaniu rozbieżności między wytworem lub czynnością naukową a danym ideałem lub oczekiwaniem (Koj, Mordyka, 1993).

Krytyka w tym opracowaniu ujęta została jako interaktywne działanie komunikacyjne, którego sens wyraża się w wartościowaniu opartym na poszukiwaniu uzasadnień formułowanych twierdzeń i przyjmowanych rozwiązań. Z kolei przez pojęcie krytyki metodologicznej rozumiana będzie taka krytyka, której przedmiotem są metodologiczne i metodyczne rozwiązania obejmujące badawcze problemy, pytania, czynności, rezultaty oraz ich uzasadnienia, w tym środki wyrazu stosowane w ich komunikowaniu. Ten sposób rozumienia odpowiada opisom i interpretacjom innych autorów (por. Hanus, 2018; Koj, Mordyka, 1993; Pelc, 1998). Krytyka metodologiczna, jak przed laty podawał Józef Pieter (1967, s. 281-282), polegać mogłaby natomiast na analizie słuszności oraz poprawności pojęć, stawiania problemów i pytań badawczych, doboru metod badawczych i przebiegu badań, sposobu opracowania materiału empirycznego, porównywaniu 
konkluzji badawczych z dotychczasowym stanem badań, jak też replikacji badań, a ponadto również na ocenie oryginalności działalności naukowej. Zarówno ta ostatnia, jak i jej wytwory bowiem mogą być poprawne w sensie metodologicznym i logicznym, lecz szablonowe. Tymczasem, jak podsumowywał Pieter (1967, s. 284-285), od badaczy oczekuje się pomysłowości i ulepszeń w zakresie metodologii prowadzonych badań, uzasadnionych - dodać by można - z punktu widzenia celów nauki.

\section{Raport empiryczny, rygor metodologiczny i krytyka}

Raport empiryczny (RE) jest środkiem komunikacji naukowej i przedmiotem, wokół którego materializuje się naukowa krytyka, w tym krytyka metodologicznych stanowisk i metodycznych rozwiązań, które przyjęte zostały w procesie badawczym. Jedno z kluczowych zadań RE to dostarczanie informacji umożliwiających ocenę wiarygodności postępowania badawczego i jego rezultatów. Kolejnym i powiązanym z pierwszym jest odtworzenie warunków gromadzenia i analizy zebranych danych celem zabezpieczenia możliwości replikacji badań i uwzględniania treści pojedynczych raportów empirycznych w metasyntezach. Formalne warunki tej oceny, replikacji i metasyntezy określa metodologia szczegółowa, która (tak jak ogólna metodologia nauk) skupiona jest przede wszystkim na zagadnieniu uzasadniania twierdzeń powstających w poznaniu naukowym (Kotarbiński, 1963) - wprowadza, opisuje, sprawdza i wartościuje instrumenty oraz procedury zabezpieczające wiarygodność poznania i możliwość oceny tej wiarygodności. Wyrazem tak ujmowanej działalności metodologicznej jest wymagany przez społeczność naukową rygor postępowania badawczego i komunikowania wyników naukowej aktywności poznawczej (Del Rosso, 2015; Czakon, 2014a, 2014b; Pasikowski, 2018; Wright, 2017), uzasadniany naukową racjonalnością.

Mimo że rygor identyfikowany bywa z czynnikami petryfikującymi strukturę i treść RE, odznacza się on czasową i środowiskową zmiennością. Innymi słowy, charakteryzuje go względna elastyczność, co łatwo zaobserwować, porównując nie tylko RE autorów reprezentujących różne dyscypliny, ale też odmienne nurty lub szkoły teoretyczne i badawcze. O ile oczekiwania i preferencje środowiska dyscyplinarnego, którego reprezentantem jest autor RE, należy traktować jako kluczowe, o tyle równie ważnymi czynnikami determinującymi zmienność RE są twórczy charakter procesu badawczego oraz kontekstualność doboru problemów, celów i rozwiązań badawczych. Niemniej definicja krytycznej granicy rygoru, której przekroczenie skutkuje traktowaniem treści RE jako niewiarygodnej, w znacznym stopniu warunkowana jest społecznie. To, co w jednym środowisku dyscyplinarnym uznawane jest za pogwałcenie rygoru, w innym 
może wynikać z lokalnych oczekiwań i preferencji. Te lokalne oczekiwania udzielają legitymizacji wybranym zbiorom odstępstw od przyjętego w dyscyplinie zbioru norm i reguł metodologicznej poprawności, metodologicznego wzorca dyscypliny. Każde odstępstwo od tej poprawności - tj. braki, błędy, nieprawidłowości - traktowane jest jako uchybienie wymagające przynajmniej rezerwy i warunkowej akceptacji. Dzieje się tak ze względu na wartość poznania naukowego, jaką jest jego wiarygodność, prowadząca w linii prostej, choć odległej, do prawdy - zarówno w sensie korespondencyjnym, gdy za cel aktywności naukowej uznawane jest odkrywanie, jak i dedukcyjnym, gdy cel identyfikuje się z budowaniem poprawnych logicznie konstrukcji intelektualnych (por. np. Białynicki-Birula, 1998, s. 44). W związku z powyższym wyróżnić można co najmniej dwie klasy uchybień: względem lokalnego standardu oraz względem uogólnionego kryterium (np. prawdy, trafności, wiarygodności, ale też intersubiektywnych kontroli i komunikowalności). Każda z nich charakteryzuje się zróżnicowaną widocznością - od postaci eksplicytnych do ukrytych. Widzialność uchybień jest cechą zależną od obserwatora. To jego dyspozycje czynią uchybienia widzialnymi, zarówno w aspekcie subiektywnym, jak i zobiektywizowanym, czyli w postaci przygotowanej do wskazania innym podmiotom. Uchybienia występujące w RE mogą być zatem mniej lub bardziej widoczne zarówno dla odbiorcy, jak i autora RE. W związku z tym na widzialność uchybień w RE spojrzeć można przez pryzmat problemu sprawczości - moralności (por. Wojciszke, 1999, 2005), co oznacza, że w grupie dyspozycji decydujących o subiektywnej oraz zobiektywizowanej widzialności uchybień znajdują się moralność oraz sprawczość. Autor może nie mieć wystarczających umiejętności lub kompetencji, by dostrzegać uchybienia. Może też wykorzystywać te sprawności do maskowania uchybień w RE, od którego oczekuje się przecież transparentnej prezentacji przebiegu badań i warunków ustalania wiarygodności ich rezultatów. Również odbiorca może dysponować zbyt małymi sprawnościami lub kierować się intencją unikania sygnalizowania uchybień. Ponadto z punktu widzenia aksjologii nauki deficyt kompetencji poznawczych po stronie autorów i konsumentów projektów naukowych wynikający z braków warsztatowych może być oddzielnie rozpatrywany w kategoriach moralnych. Podobnie zresztą w kategoriach moralnych można rozpatrywać kwestię doskonalenia kompetencji badawczych, w tym krytycznego myślenia.

\section{Model krytyki metodologicznej}

Model przedstawiony na rysunku opisuje krytykę metodologiczną, opierając się na trzech głównych wymiarach. Są to: świadomość nadawcy w zakresie generowania uchybień (X), identyfikacja występowania uchybień przez odbiorcę (Y) oraz rygoryzm metodologiczny środowiska dyscyplinarnego (Z). 
Symbolizują je osie X, Y i Z. Obszar pomiędzy nimi tworzy przestrzeń lokalnej legitymizacji odstępstw lub uchybień. Oznaczona jest ona przerywaną linią. Poza jej granicami znajduje się przestrzeń nieakceptacji odstępstw. W modelu krytyki punktem odniesienia podczas oceny uchybień czynić należy dane teorie lub modele wyznaczające działanie. Zachodzące odstępstwo dotyczy więc poprawności względem wzorca i tego działania. Jeśli więc działanie odbiega od wzorca uzasadnianego teorią lub modelem, stanowi to podstawę do orzekania odstępstwa od poprawności. Mowa tu więc o poprawności w ramach lokalnie przyjętego systemu teoretycznego ${ }^{1}$, a nie zobiektywizowanego i uniwersalizowanego wzorca. To z kolei umożliwia dostrzeżenie, iż podstawową przeszkodą w toczeniu racjonalnych dyskusji w ramach fikcyjnych systemów bywają uprzedzenia dyskutantów kierujących się założeniem prymatu korespondencji teorii z doświadczeniem.

Świadomość zaistniałych oraz potencjalnych uchybień w postępowaniu badawczym i jego prezentacji realizowanej za pomocą raportu z badań określa relację zachodzącą pomiędzy nadawcą i odbiorcą. Polega ona na wzajemnym przewidywaniu reakcji oraz formułowaniu na nie odpowiedzi. To założenie ma swoje źródło w idei strategii tekstowych Umberta Eco (1987 [1979]), o czym pisałem w innym miejscu (Pasikowski, 2018). Zwracałem tam również uwagę, że dostrzeganie odchyleń od wzorca postępowania naukowego uzależnione jest od wiedzy i umiejętności, które składają się na świadomość metodologiczną. Tu dodam, że nie mniejszą rolę odgrywać mogą czynniki współtworzące warunki przetwarzania informacji zarówno przez nadawcę, jak i odbiorcę. Należą do nich emocje, motywacja czy uwaga, w tym obecność wewnątrz- i zewnątrzpodmiotowych dystraktorów. Na tym etapie opracowania modelu krytyki metodologicznej zostają one jednak pominięte. Model przewiduje, że stopień identyfikacji występowania uchybień charakteryzujący odbiorcę (O) wyznaczy jego reakcje i decyzje w zakresie oceny wartości RE i zawartej w nim treści. Z kolei stopień świadomości generowania uchybień po stronie nadawcy (N) wyznaczy postać RE, w tym repertuar odpowiedzi na reakcje odbiorcy względem jego treści. Środowiska dyscyplinarne w różnym stopniu wymagają od swych reprezentantów przestrzegania charakterystycznego dla dyscypliny standardu poprawności, notabene, tym bardziej jasnego i rygorystycznego, im silniejszy rygoryzm tego środowiska. W związku z tym środowiska te cechować będą się zróżnicowanym zakresem nieakceptacji odstępstw od poprawności metodologicznej. Granica tej nieakceptacji rozmywa się wraz ze spadkiem rygoryzmu dyscypliny. Na rysunku można by to oddać szerokością krawędzi przestrzeni legitymizacji (ostrosłupa) rosnącą w kierunku od wewnątrz modelu.

1 Ustalanie prawdziwości twierdzeń, także w sensie wartości logicznej, jest możliwe również w systemach fikcyjnych, o ile odniesienie twierdzeń będzie wewnętrzne, tzn. zlokalizowane w ramach takiego systemu, a nie poza nim (Paśniczek, 1984). 


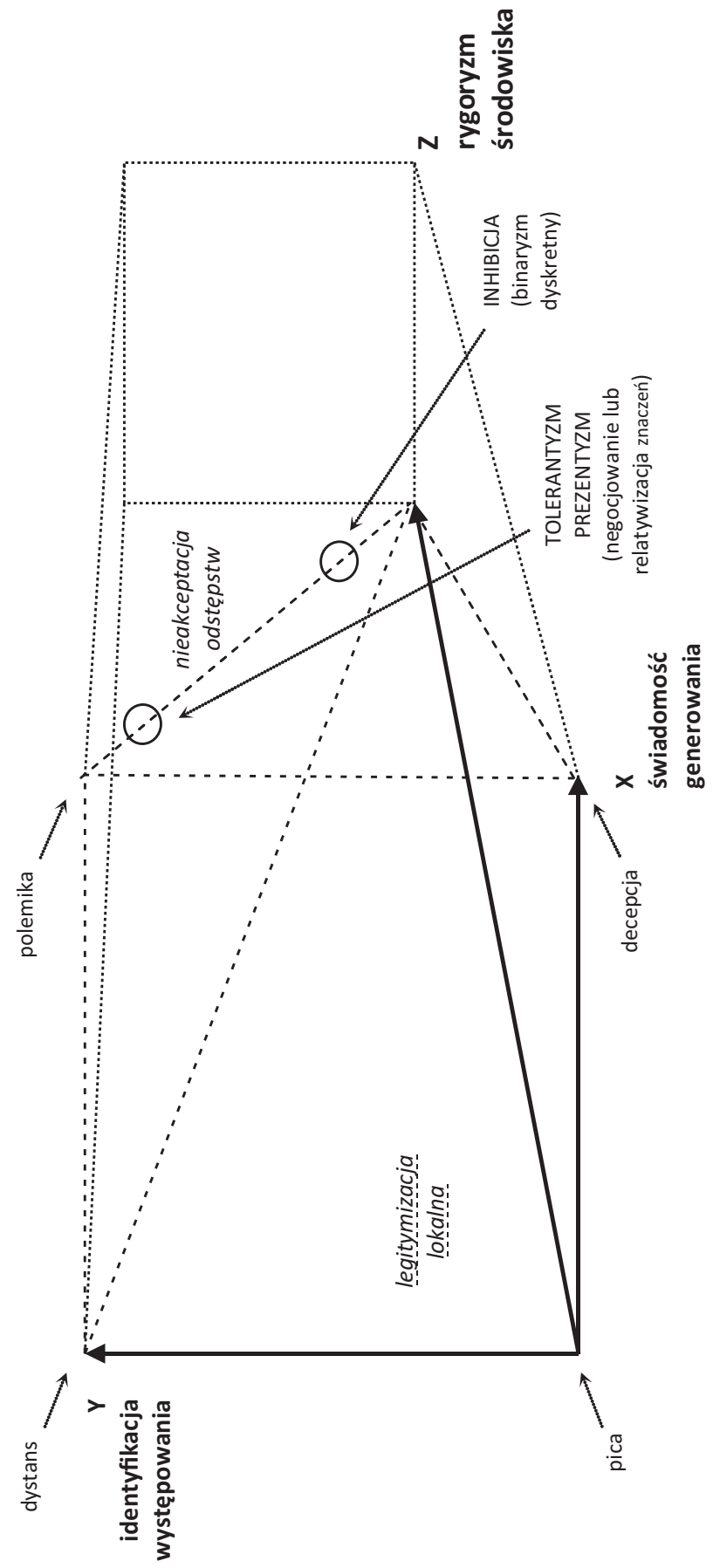

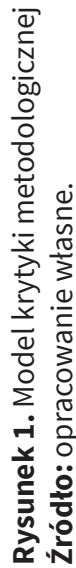


W przypadku środowisk o wysokim stopniu rygoryzmu ich reprezentanci nie muszą cechować się rozwiniętą świadomością metodologiczną, aby unikać odstępstw od metodologicznej poprawności, gdyż w dyscyplinie istnieją mechanizmy środowiskowej kontroli. Innymi słowy, autorzy i krytycy nie mają zbyt wielu okazji do powątpiewania w nieodstępowanie od standardu poprawności, bo środowisko dysponuje wypracowanymi i utrwalonymi zewnętrznymi mechanizmami kontrolowania poprawności metodologicznej wytworów już w procesie ich powstawania.

Z kolei w środowiskach o niskim stopniu rygoryzmu wysoki poziom świadomości metodologicznej może nie mieć większego znaczenia w zabezpieczaniu RE i jego odczytań przed uchybieniami, głównie ze względu na wysoką akceptowalność wytworów niezależnie od charakteru i stopnia tychże uchybień. Autorzy nie muszą przywiązywać większej wagi do poprawności i zbytnio obawiać się nieakceptacji przyjmowanych rozwiązań w zakresie prowadzonych badań i ich prezentacji, bo środowisko nie sankcjonuje uchybień - ono je redefiniuje lub nawet ich nie zauważa. $Z$ kolei odbiorcy nie mają $w$ takim środowisku stabilnego punktu odniesienia w ocenie zawartości RE. Zboczenie z kursu metodologicznej poprawności lub przestrzegania metodologicznych pryncypiów zatem nie mieści się w polu wyobrażeń wiedzy, które dominują w takim środowisku albo pozostaje na ich marginesie.

Przestrzeń legitymizacji lokalnej wiąże się z akceptacją przyjmowanych rozwiązań (tj. aplikacji oraz deficytów w zakresie określonych czynności, metod, procedur, środków) dających się odczytać z RE. Dzieje się tak niezależnie od poziomu świadomości nadawcy i odbiorcy. To oznacza, że zamierzone rozwiązania, postrzegane zarówno przez $\mathrm{N}$, jak i O jako możliwe nadużycia, nie zostaną potraktowane jako nieprawomocne w środowisku dyscyplinarnym, którego przestrzeń legitymizacji je obejmuje. RE zostanie więc skonsumowany $\mathrm{w}$ ramach dominującego $\mathrm{w}$ dyscyplinie lub społeczności naukowej tolerantyzmu (por. Piekarski, 2010). Jednakże wraz z pomniejszaniem się przestrzeni legitymizacji zwiększa się szansa sankcjonowanego środowiskowo zróżnicowania postaci reakcji (sytuacji komunikacyjnych). Rośnie bowiem tym samym udział świadomości N i O w decydowaniu o zaakceptowaniu RE. Wówczas im wyższy poziom świadomości (identyfikacji) uchybień (O), tym bardziej stanowcze i mniej dyskusyjne odrzucenie treści $R E$, o ile, co warto podkreślić, uchybienie nie mieści się w przestrzeni legitymizacji lokalnej. Należy jednak zwrócić uwagę, że uchybienia lokujące się na granicy tej przestrzeni generować będą duże zróżnicowanie reakcji i coraz mniejsze możliwości ich sytuacyjnego przewidywania (rozmytość zbioru elementów akceptowanych). Z kolei im wyższy poziom świadomości generowania uchybień $(\mathrm{N})$, tym większa dbałość o stosowanie zabezpieczeń RE przed odrzuceniem, wyrażająca się obudowywaniem argumentacyjnym słabych stron zastosowanych rozwiązań lub 
maskowaniem słabości, np. przez wprowadzanie wymyślnych rozwiązań dodatkowych lub pomijanie i manipulowanie informacjami, które mogłyby wskazywać na obecność uchybień. Tu również z uchybieniami znajdującymi się na granicy przestrzeni legitymizacji związane będą większy udział czynników indywidualnych (osobowościowych) w wyznaczaniu działań nadawcy oraz mniejsza możliwość ich przewidywania ex ante.

Legitymizacja lokalna, w tym jej zakres, warunkowana jest historycznie i jest też temporalnie zmienna. Zależy m.in. od bieżących zdolności i umiejętności reprezentantów środowiska dyscyplinarnego, choć kluczowa rola w określaniu jej zakresu przypada głównie znaczącym reprezentantom tego środowiska.

Związek między świadomością uchybień a zakresem ich lokalnej legitymizacji wyraża się też na innej płaszczyźnie. Badacze z reguły wiedzą, gdzie znajduje się granica środowiskowej akceptowalności stosowanych rozwiązań i sądów. Określa ją społeczna świadomość metodologiczna (Spendel, 2005), którą charakteryzuje się środowisko społeczne danej dyscypliny. Innymi słowy, należy założyć zbieganie się przestrzeni legitymizacji z coraz niższym poziomem świadomości w miarę wzrostu rygoryzmu metodologicznego dyscypliny (to też przewiduje prezentowany model), gdyż wzrost ten stopniowo ogranicza dopuszczalność odstępstwa od metodologicznej poprawności. Wynika to z dysponowania przez środowisko dyscyplinarne standardem poprawności, który powszechnie promuje ono za sprawą treningu metodologicznego, jakiemu podlegają adepci dyscypliny. To natomiast pozwala oczekiwać występowania u przedstawicieli danego środowiska dyscyplinarnego ogólnej, mniej lub bardziej uświadamianej wrażliwości na przyjmowaną przez to środowisko granicę nieakceptacji odstępstw od poprawności metodologicznej.

Przyjąć też można, że odstępstwa od przyjętej w środowisku poprawności, o ile nie są zamierzone, wynikają przynajmniej w jakimś zakresie z niedostatecznej indywidualnej świadomości metodologicznej.

W związku z powyższym: (1) wraz ze wzrostem stopnia rygoryzmu dyscypliny coraz mniejszy zakres świadomości uchybień pokrywa się z zakresem legitymizacji, a także (2) krawędzie przestrzeni legitymizacji lokalnej zbiegają się w punkcie 0 osi świadomości (X i Y) dla zmaksymalizowanego natężenia rygoryzmu środowiska dyscyplinarnego $(Z)$.

W proponowanym modelu granice przestrzeni legitymizacji lokalnej zbiegają się w układzie współrzędnych do punktu 0 (osi X i Y) wraz ze wzrostem rygoryzmu dyscypliny (Z). Innymi słowy, przestrzeń legitymizacji lokalnej uchybień związana jest ujemnie z rygoryzmem, co nie powinno zaskakiwać. Rysunek pokazuje, że wraz ze wzrostem rygoryzmu metodologicznego środowiska niski poziom indywidualnej świadomości uchybień ma coraz mniejsze szanse pokrywania się z przestrzenią legitymizacji lokalnej, a to oznacza, że coraz trudniej znajdować dla nich uzasadnienie 
w panujących zwyczajach środowiska dyscyplinarnego. Zmniejszające się pokrycie przestrzeni legitymizacji ze świadomością uchybień nie oznacza jednak, iż indywidualny reprezentant rygorystycznego środowiska dyscyplinarnego charakteryzuje się niskim poziomem świadomości występowania uchybień. Tego wywieść z modelu nie można. Oznacza raczej, że w przypadku środowisk dyscyplinarnych o niskim poziomie legitymizacji uchybień nacisk na jasność standardu poprawności i nieakceptacji odstępstw jest na tyle silny i konsekwentny, że ich reprezentanci już w toku treningu dyscyplinarnego wyposażani są w schematy postępowań, które umożliwiają im, nawet przy niskim poziomie indywidualnej świadomości metodologicznej, tworzenie naukowych wytworów w sposób niekolidujący ze środowiskowo określonym standardem metodologicznej poprawności. Asekuracja poprawności jest dodatkowo wzmacniana już w trakcie „normalnego” funkcjonowania w środowisku dyscyplinarnym dzięki istnieniu możliwie jasno określonej granicy akceptowalności czynności i wytworów naukowych. Środowisko to koryguje odpowiednio wcześnie nie tylko uchybienia, ale też ryzyko ich powstawania. Wykorzystane w tym korygowaniu mogą być nieformalne recenzje, konsultacje, uwagi, nagłaśnianie przypadków uchybień itp., co skutkuje zwiększeniem wyrazistości uchybienia na tle jasnego i powszechnie przestrzeganego standardu poprawności. Dopóki środowisko dyscyplinarne wyznacza bezdyskusyjnie standard poprawności, dopóty reprezentanci o niskim poziomie świadomości metodologicznej mogą polegać na automatyzacji operacji i procedur, tzn. na ich niekoniecznie refleksyjnym stosowaniu. W związku z tym rozwinięta indywidualna świadomość metodologiczna nie jest niezbędna w procesie tworzenia wiarygodnych wytworów naukowych. Należy jednak dysponować nieprzeciętnym poziomem świadomości, aby wykroczyć poza granice dyscyplinarnej legitymizacji, wyznaczane standardem panujących w środowisku oczekiwań i norm jakości wytworów naukowych oraz stosowanych procedur uzasadniania.

Interesujących przewidywań dostarcza model w zakresie wzorów reakcji na uchybienia występujące w RE. Jeśli znajdą się one poza przestrzenią legitymizacji, odrzucenie zawierającego je RE albo jego fragmentów uzyskuje środowiskowe usankcjonowanie. Tym samym prawdopodobieństwo odrzucenia staje się dużo wyższe. Z kolei uchybienia ulokowane w pobliżu granicy przestrzeni legitymizacji lokalnej (na rysunku przedstawione jako pętle na przerywanej linii) wzbudzać będą reakcje ambiwalentne i trudniejsze do przewidzenia, na przykład skutkujące warunkową akceptacją albo próbami powstrzymywania się od decyzji w ocenie treści RE.

W zależności od świadomości N i O oraz rygoryzmu środowiska dyscyplinarnego reakcje na uchybienia można próbować klasyfikować przy użyciu ogólniejszych kategorii. O ile redukuje to eksplanacyjny potencjał modelu akceptowalności krytyki, przede wszystkim z uwagi na kłopot 
z wyznaczaniem granicy między klasami, o tyle stanowić może ułatwienie w koncepcyjnym porządkowaniu przestrzeni możliwych zdarzeń i postaci takich reakcji oraz w zapoznawaniu się z możliwościami tego modelu. Po pierwsze, można wskazać klasę relacji N-O. Po drugie, klasę rygoryzmów.

Model pozwala wyodrębnić cztery typy relacji pomiędzy $\mathbf{N}$ i $\mathbf{O}$ organizujących się wokół RE w zależności od stopnia świadomości odchyleń od wzorca metodologicznej poprawności. Pierwszy typ zachodzi w sytuacji niskiego natężenia świadomości generowania oraz występowania uchybień. Niski poziom świadomości N i O powoduje, że treść RE, a wraz z nią uchybienia oraz bezzasadne, a niekiedy absurdalne sądy, podlegać będą konsumpcji. $Z$ tego powodu typ ten nazwany został pica przez analogię do określanego tą nazwą zaburzenia łaknienia, wyrażającego się spożywaniem rzeczy nienadających się do konsumpcji. Dystans to drugi typ relacji, który charakteryzują niski poziom świadomości generowania $(\mathrm{N})$ i dostatecznie wysoki poziom świadomości występowania uchybień (O). Świadomy odbiorca z dystansem i rezerwą przyjmuje $R E$. $Z$ tą relacją mogą wiązać się działania O i N ukierunkowane na korektę RE. Trzeci typ nazwany został decepcją i charakteryzuje się dostatecznie wysokim poziomem świadomości generowania $(\mathrm{N})$ i niskim poziomem świadomości występowania uchybień $(\mathrm{O})$. O ulega efektom działań $\mathrm{N}$ nastawionym na maskowanie uchybień występujących w RE. Czwarty typ charakteryzuje się dostatecznie wysokim poziomem świadomości generowania $(\mathrm{N})$ i występowania uchybień $(\mathrm{O})$ i nosi nazwę polemika ze względu na warunki obu stron sprzyjające toczeniu dyskusji, przywoływaniu argumentacji i negocjowaniu stanowisk. W przypadku gotowego RE rzadko dochodzić może do bezpośredniej polemiki. Chodzi raczej o przewidywanie zachowań wirtualnego interlokutora i podejmowanie reakcji, które polegać mogą na dyskutowaniu z kilkoma scenariuszami argumentacji (tak mogłoby być po stronie O) lub obudowywaniu uzasadnieniami określonych rozwiązań przyjętych podczas realizacji badań lub ich opisu (takie reakcje mógłby podejmować $\mathrm{N}$ ).

Model uwzględnia także rolę, jaką w wyznaczaniu typów relacji $\mathrm{N}-\mathrm{O}$ odgrywa rygoryzm środowiska dyscyplinarnego. Przewiduje on, że szansa zachodzenia wyróżnionych typów relacji zależy od rygoryzmu środowiska dyscyplinarnego, aczkolwiek prawdopodobieństwo występowania tych relacji ograniczone jest przestrzenią legitymizacji lokalnej. Na rysunku obrazuje to krawędź ostrosłupa oznaczonego przerywaną linią. Przy niskim poziomie rygoryzmu N, o ile dostrzeże uchybienia w RE, z łatwością bronić może jego treści, odwołując się choćby do argumentów relatywizujących kategorie błędu, nieprawidłowości, wzorca czy odchyleń. W związku z niejednoznacznością standardów lub ich liberalnym traktowaniem nacisk na forsowanie RE będzie mógł wówczas odgrywać ważniejsza rolę niż identyfikacja uchybień i świadomość ich występowania. Z kolei wysoki poziom rygoryzmu środowiska dyscyplinarnego skutkować będzie uruchamianiem 
procedur korygujących, odwołujących się do jasno określonego standardu istniejącego w takich środowiskach, oraz polemik. Obecność wyraźnego standardu tłumaczy, dlaczego podczas charakterystyki typów relacji mowa jest o dostatecznie wysokim poziomie świadomości O lub N. Chodzi bowiem o świadomość przynajmniej w zakresie standardu obowiązującego w środowisku dyscyplinarnym.

W zależności od przewagi natężenia świadomości uchybień sprawczość wzbudzania i podtrzymywania typów relacji przechylać będzie się na stronę bardziej świadomego uczestnika tejże relacji. Należy jednak brać pod uwagę, że szanse pojawiania się tych relacji zależą przede wszystkim od poziomu rygoryzmu dyscypliny. Postać relacji współwyznaczana jest więc przez legitymizację lokalną. Szczególnie gdy mowa o relacji zinstytucjonalizowanej, takiej jak np. ta zachodząca w warunkach instytucjonalnej recenzji. Jeśli więc $\mathrm{N}$ lub $\mathrm{O}$ charakteryzować się będą niższym stopniem świadomości niż ten wyznaczany granicą legitymizacji lokalnej, to uchybienia (odstępstwa od poprawności) mogą być przez nich niezauważane pomimo nieakceptowalności z punktu widzenia standardu przyjętego w środowisku dyscyplinarnym. Z kolei wyższy poziom świadomości N lub O nie musi wzbudzać ich troski o środowiskową akceptację wytworów i rozwiązań. Nie może też poważnie tej akceptacji zachwiać z powodu granicy tolerancji przyjętej w środowisku dyscyplinarnym. Dystans, polemika oraz decepcja tracą wówczas moc wzbudzania reakcji. Nie są bowiem uzasadnione kontekstem dyscyplinarnej nieakceptowalności. Maksymalizacja świadomości N i O ukierunkowuje relację w stronę polemiki, a minimalizacja - w stronę pica.

Kwestię rygoryzmu można również ująć w kategorie typów. W zależności od stopnia jego nasilenia mowa będzie o binaryzmie dyskretnym, negocjowaniu oraz relatywizacji znaczeń uchybień. Ten pierwszy wiąże się z gotowością do jednoznacznego rozstrzygania poprawności działań, niekiedy według zasady „wszystko albo nic”, przez odwołanie do jasnego standardu. W przypadku tej postaci rygoryzmu rozstrzyganie zgodności ze wzorcem jest z reguły instytucjonalizowane. Przewaga odpowiedzialności nie leży po stronie świadomych metodologicznie $\mathrm{N}$ i O. Z kolei negocjowanie znaczeń uchybień to postać rygoryzmu dopuszczająca dyskusję, formułowanie komentarzy i argumentowanie za przyjmowanymi decyzjami i działaniami. Wreszcie relatywizacja znaczeń uchybień wiąże się z uznawaniem względności każdego rozwiązania i stanowiska. W tym wypadku pojęcie uchybienia wraz z pojęciem wzorca metodologicznej poprawności stają się wątpliwe, przez co akceptacja RE jest zdecydowanie mniej uzależniona od kryteriów metodologicznych.

Wyróżnione typy korespondują z wzorami praktyki ujętymi w koncepcji Jacka Piekarskiego (2010; tekst w tym tomie). Są to odpowiednio inhibicja, tolerantyzm oraz prezentyzm. Jednak reakcje reprezentujące powyższe 
typy różnicowane będą przede wszystkim ze względu na stopień świadomości (także metodologicznej) nadawcy i odbiorcy RE, tj. przekazu. Klasy powstające $z$ układu typów relacji oraz typów rygoryzmów stanowią zbiory specyficznych postaci praktyk metodologicznych w zakresie omijania przeszkód (gdy założyć, że uchybienia to problem przeszkody epistemologicznej po stronie odbiorcy) tudzież eliminowania uchybień (przeszkoda generowana przez nadawcę). Poglądową próbę określenia zakresu, w jakim mogą one występować w przestrzeni krytyki metodologicznej, zaprezentowano w tabeli.

Tabela 1. Przewidywany zakres występowania typów relacji w zbiorze możliwych w zależności od rygoryzmu dyscypliny

\begin{tabular}{|l|c|c|c|c|}
\hline \multirow{2}{*}{\multicolumn{1}{|c|}{ Typ rygoryzmu }} & \multicolumn{4}{c|}{ Typ relacji } \\
\cline { 2 - 5 } & pica & decepcja & dystans & polemika \\
\hline Binaryzm dyskretny & + & ++ & ++ & +++ \\
\hline Negocjowanie znaczeń & ++ & ++ & ++ & ++ \\
\hline Relatywizacja znaczeń & +++ & ++ & ++ & + \\
\hline
\end{tabular}

+ - mały zakres, ++ - umiarkowany zakres, +++ - duży zakres

Źródto: opracowanie własne.

Wyeksponowany zakres należy odczytywać tylko w poprzek wymiaru rygoryzmu, tzn. wewnątrz danego typu. Stąd, biorąc jako przykład dystans i polemikę, mogą one zdarzać się nawet częściej w relatywizacji niż w binaryzmie, lecz w ramach tej pierwszej wyraźnie rzadziej niż pica. Mowa tu wprawdzie stale o rygoryzmie, jednak pamiętać należy, że prawdopodobieństwo ich wystąpienia zwiększać się może w przestrzeni legitymizacji lokalnej.

Na koniec tej sekcji zaryzykuję wyprowadzenie z modelu następującej konkluzji: $w$ środowiskach dyscyplinarnych ${ }^{2}$ o umiarkowanym stopniu rygoryzmu należałoby spodziewać się najbardziej twórczych i rozwijających form radzenia sobie z uchybieniami. Do tego bowiem potrzeba nie tylko indywidualnej świadomości metodologicznej, ale też warunków leżących po stronie środowiska dyscyplinarnego, którego standard poprawności nie jest zbyt liberalny, ale jednocześnie nie jest zanadto konserwatywny. W przeciwnym przypadku zagrożeniem dla twórczości są niekontrolowana akceptacja treści i relatywizacja znaczenia uchybień albo znacznie ograniczone warunki odchodzenia od standardu i istnienie zabezpieczeń wychwytujących odchylenia, co w rezultacie utrudnia pojawianie się oryginalnych rozwiązań.

2 Ryzykownie jest przyjmować, że model dotyczy całych dyscyplin. Można bowiem wskazać przykłady oszustw i uchybień w obrębie tych z nich, które uchodzą za rygorystyczne (np. loannidis, 2005; Krimsky, 2006). Opisuje on więc środowiska i grupy społeczne wyodrębniające się $w$ ramach danej dyscypliny. 


\section{Funkcje modelu}

Najogólniej rzecz ujmując, model stwarza warunki przewidywania reakcji społeczności naukowej na publikowany RE. Zgodnie z nim reakcje grupy lub społeczności na występujące w RE uchybienia uzależnione będą od zakresu legitymizacji lokalnej. Uchybienia leżące poza przestrzenią legitymizacji spotkają się ze zdecydowanym odrzuceniem, te lokujące się na granicy przestrzeni legitymizacji zaś wzbudzać będą reakcje niejednoznaczne i dzielące audytorium, tym bardziej, im bliżej tej granicy zostaną zlokalizowane oraz $\mathrm{w}$ im większym stopniu granica ta charakteryzować się będzie rozmytością. Założyć można, że rozmytość granicy ujemnie związana jest ze stopniem rygoryzmu dyscypliny.

Po operacjonalizacji model mógłby stanowić podstawę tworzenia instrumentarium do oceny akceptowalności RE (wiarygodności, jaka jest mu przypisywana), jego perswazyjności oraz szans na aplikację zawartej w nim treści. Jednak przede wszystkim służyć może opisywaniu wzorów krytyki metodologicznej (wyznaczanych warunkami, które model uwzględnia, tj. świadomością oraz legitymizacją) i odkrywaniu różnorodnych jej postaci przez penetrację wskazanych przez niego obszarów oraz przewidywaniu kierunku, w którym kształtować się może relacja pomiędzy N (np. autorem) i O (np. krytykiem).

Metaperspektywa, którą dostarcza model krytyki metodologicznej, stwarza okoliczności do definiowania i określania relewantności krytyki (i krytyka) względem warunków tła, czyli kontekstu dyscyplinarnych oczekiwań. Ma też inne konsekwencje: badając granicę legitymizacji środowiskowej, umożliwia celowanie $\mathrm{w}$ różnice międzydyscyplinarne w zakresie tolerancji uchybień oraz akceptowalności w polu krytyki.

Podsumowując, zaprezentowany model umożliwia kreślenie scenariuszy zachowania środowiska dyscyplinarnego (przez odwołanie do przestrzeni legitymizacji lokalnej i jej granic), zachowania krytyka (indywidualna świadomość metodologiczna i świadomość legitymizacji lokalnej), zachowania badacza i autora (rozwiązania argumentacyjne albo ich brak w sytuacji generowania uchybień) oraz pozwala charakteryzować warunki perswazyjności wytworów naukowych, takich jak np. RE.

\section{Zakończenie}

Model krytyki metodologicznej prac badawczych ma zalety i wady charakterystyczne dla modeli stanowiących $w$ istocie poznawcze reprezentacje. Oznacza to, że choć pozwala on wiązać pojęcia i symulować zachodzące pomiędzy nimi relacje wyznaczające postać modelowanego zjawiska, 
jednocześnie deformuje jego obraz na drodze abstrakcji i idealizacji. Co więcej, eksplanacyjna oraz prognostyczna wartość modelu weryfikuje się w kontrolowanym doświadczeniu. W tym kontekście jego ważną bieżącą zaletą jest jednak to, że przedstawia związki między składnikami w postaci funkcji, co stwarza podstawę do modelowania krytyki metodologicznej także w sensie matematycznym. W rezultacie jego empiryczne testowanie zyskiwać może na przejrzystości.

$\mathrm{Na}$ bazie idealizacyjnego podejścia w modelowaniu krytyki zostało $w$ tekście zaproponowane również ujęcie typologiczne. Ma ono jednak charakter wyłącznie poglądowy, z konieczności bowiem upraszcza zaprezentowany model, choć pozwala wyeksponować związki rygoryzmu oraz relację $\mathrm{N} \mathrm{i} \mathrm{O,} \mathrm{a} \mathrm{przez} \mathrm{to} \mathrm{uwidocznić} \mathrm{możliwości} \mathrm{posługiwania} \mathrm{się} \mathrm{modelem}$ w tworzeniu przewidywań działań komunikacyjnych podejmowanych przez odbiorcę raportu empirycznego.

Kolejną kwestią wartą podkreślenia na zakończenie jest to, iż model pozwala spojrzeć na konwencjonalizm metodologiczny nie od strony przyjętej reguły lub wzorca, jak zwykło się to czynić, lecz od strony odchylania się od nich. Oddaje to właśnie idea legitymizacji lokalnej. Prezentowany model uwzględnia również relacje pomiędzy tak pojmowanym konwencjonalizmem a rygoryzmem metodologicznym, wyrażającym się w obiektywizowanych kryteriach metodologicznych, niekoniecznie w pełni uświadamianych podczas ich aplikacji w praktyce badawczej. Stwarza tym samym okazję dostrzeżenia napięcia pomiędzy składnikami tej relacji.

Przywoławszy pojęcie legitymizacji lokalnej, wypada jeszcze w tym miejscu skomentować pojęcie fikcji i zachodzącej między nimi relacji. Ta pierwsza ma zdolność sankcjonowania tej ostatniej, rozumianej choćby zgodnie z warunkami korespondencyjnej koncepcji prawdy. Nie rozwijając dyskusji, pragnę zwrócić jedynie uwagę, że o ile legitymizacja lokalna sankcjonować może fikcję, o tyle logika fikcji w kontekście zagadnienia krytyki ma raczej status środka wspierającego poszukiwanie wartościowych składników krytykowanego wytworu. Zabezpiecza ona te składniki przed odrzuceniem z powodu braku zbieżności ze stanem uznawanym za rzeczywistość czy też z oczekiwaniami krytyka - innymi jednak niż poprawne rozumowanie w ramach przyjętego systemu twierdzeń, reguł i metod. To kwestia zasługująca na oddzielną dyskusję poświęconą efektywności krytyki metodologicznej i analizy jej kryteriów.

\section{Bibliografia}

Ajdukiewicz, K. (1965). Język i poznanie (t. 2). Warszawa: PWN.

Ajdukiewicz, K. (1983). Zagadnienia i kierunki filozofii. Warszawa: Czytelnik.

Białynicki-Birula, A. (1998). Rzecz o krytyce naukowej (s. 43-50). W: H. Żytkowicz (red.), Krytyka i krytycyzm w nauce. Warszawa: Fundacja na rzecz Nauki Polskiej. 
Czakon, W. (2014a). Kryteria oceny rygoru metodologicznego badań w naukach o zarządzaniu. Organizacja i Kierowanie, 1(161), 51-62.

Czakon, W. (2014b). Metodologiczny rygor w badaniach nauk o zarządzaniu. Prace Naukowe Uniwersytetu Ekonomicznego we Wrocławiu, 340, 37-45.

Del Rosso, R.J. (2015). Our New Three Rs: Rigor, Relevance, and Readability. Governance: An International Journal of Policy, Administration, and Institutions, 28(2), 127-130.

Descartes, R. (2002). Reguły kierowania umysłem. Poszukiwanie prawdy poprzez światło naturalne. Kęty: Wydawnictwo Antyk.

Descartes, R. (2009). Rozprawa o metodzie. Kęty: Wydawnictwo Marek Drzewiecki.

Goćkowski, J. (1998). Krytyka naukowa a style uprawiania nauki (s. 66-69). W: H. Żytkowicz (red.), Krytyka i krytycyzm w nauce. Warszawa: Fundacja na rzecz Nauki Polskiej.

Goćkowski, J. (2001). Krytyka naukowa a reguły gry o prawdę naukową. Nauka i Szkolnictwo Wyższe, 2(18), 73-81.

Hanus, A. (2018). Krytykowanie i jego operacjonalizacja w kontrastywnej analizie dyskursu. Warszawa-Dresden: ATUT / Neisse Verlag.

Ioannidis, J.P. (2005). Why Most Published Research Findings Are False? PLOS Medicine, 2(8), e124.

Jackowski, S. (1998). Krytyka, czyli sztuka porównań (s. 70-73). W: H. Żytkowicz (red.), Krytyka i krytycyzm w nauce. Warszawa: Fundacja na rzecz Nauki Polskiej.

Koj, L., Mordyka, C. (1993). Krytyka, rozumienie i ocena (s. 75-88). W: L. Koj, Wątpliwości metodologiczne. Lublin: Wydawnictwo UMCS.

Kotarbiński, T. (1963). Elementy teorii poznania, logiki formalnej i metodologii nauk. Warszawa: PWN.

Krimsky, S. (2006). Nauka skorumpowana? O niejasnych związkach nauki i biznesu. Warszawa: PIW.

Pasikowski, S. (2018). Standard „niewiedzy” lub ucieczka od transparentności? Ekspresje rygoru metodologicznego w raportach z badań. Edukacja Dorosłych, 2(79), 149-161.

Paśniczek, J. (1984). Logika fikcji. Esej o pewnej logice typu meningowskiego. Lublin: Wydawnictwo Uczelniane UMCS.

Pelc, J. (1998). Krytyka i krytycyzm w nauce (s. 7-25). W: H. Żytkowicz (red.), Krytyka i krytycyzm w nauce. Warszawa: Fundacja na Rzecz Nauki Polskiej.

Piekarski, J. (2010). Kryteria waloryzacji praktyki badawczej - między inhibicją metodologiczną a permisywnym tolerantyzmem (s. 151-173). W: J. Piekarski, D. Urbaniak-Zając, K. Szmidt (red.), Metodologiczne problemy tworzenia wiedzy w pedagogice. Oblicza akademickiej praktyki. Kraków: Oficyna Wydawnicza „Impuls”.

Pieter, J. (1967). Ogólna metodologia pracy naukowej. Wrocław-Warszawa-Kraków: Zakład Narodowy im. Ossolińskich, Wydawnictwo Polskiej Akademii Nauk.

Popper, K. (1962). Conjectures and Refutations. The Growth of Scientific Knowledge. New York, London: Basic Books.

Sławiński, J. (1998). Poniewczasie (s. 95-97). W: H. Żytkowicz (red.), Krytyka i krytycyzm w nauce. Warszawa: Fundacja na rzecz Nauki Polskiej.

Spendel, Z. (2005). Metodologia badań psychologicznych jako forma świadomości historycznej. Katowice: Wydawnictwo UŚ.

Sternberg, R.J. (2011). Recenzowanie prac naukowych w psychologii. Warszawa: Paradygmat.

Szacki, J. (1998). O krytyce naukowej (s. 51-55). W: H. Żytkowicz (red.), Krytyka i krytycyzm w nauce. Warszawa: Fundacja na rzecz Nauki Polskiej.

Świderski, J. (1998). Krytyka jako pomiar (s. 82-83). W: H. Żytkowicz (red.), Krytyka i krytycyzm w nauce. Warszawa: Fundacja na Rzecz Nauki Polskiej.

Wojciszke, B. (1999). Grzech czy porażka? Moralne i sprawnościowe kategorie w potocznym rozumieniu świata społecznego (s. 34-51). W: B. Wojciszke, M. Jarymowicz (red.), Psychologia rozumienia zjawisk społecznych. Warszawa: Wydawnictwo Naukowe PWN.

Wojciszke, B. (2005). Morality and Competence in Other- and Self-perception. European Review of Social Psychology, 16(1), 155-188.

Wright, R. (2017). Academic Rigor or Academic Rigor Mortis? Adult Learning, 28(1), 35-37. 


\title{
Conditions of methodological critique in research
}

\begin{abstract}
SUMMARY
The chapter presents a model of research critique using the idea of deviations from the pattern of methodological correctness. The author introduces the concept of two categories of such deviations: from the local standard and from the generalized criterion. Both refer to the concept of visibility, which co-determines the scope of the response on the side of the sender as well as of the receiver of the empirical report. As a consequence, the author proposed a model of methodological critique that refers to the awareness of failures, defining the conditions of visibility of deviations, and methodological rigor in the discipline, which determines the scope of environmental legitimacy of these deviations. The model makes it possible to predict the behaviour of the creator, the recipient and the disciplinary community in which the report is presented, as well as to characterize the persuasiveness of scientific communication by the empirical reports.
\end{abstract}

Keywords: critique, legitimization, rigor, methodological rigor, methodological failures, trustworthiness of empirical research 